\title{
Expression of an engrailed-like Gene During Development of the Early Embryonic Chick Nervous System
}

\author{
C.A. Gardner, D.K. Darnell, S.J. Poole, C.P. Ordahl, and K.F. Barald \\ Department of Anatomy and Cell Biology, University of Michigan, Ann Arbor, (C.A.G., K.F.B.): \\ Departments of Anatomy (D.K.D., C.P.O.) and of Biochemistry and Biophysics (S.J.P.), University of \\ California, San Francisco
}

The engrailed gene has been identified in Drosophila as an important developmental gene involved in the control of segmentation. Here we describe the embryonic expression of a chicken gene, ChickEn (Darnell et al.: J Cell Biol 103(5):311a, 1986), which contains homology to the Drosophila engrailed gene. Northern blots of early chick embryo tissue poly $(A)^{+}$RNA resulted in hybridization to at least three bands expressed predominantly in the brain/head region when probed with ChickEn genomic fragments. Eight cDNA clones generated from embryonic day 6 (stage 29-30) chick brain poly(A) ${ }^{+}$RNA are identical in their nucleotide sequence with the ChickEn genomic clone. In situ hybridization to sections of 4-day (stage 24) embryos indicated that ChickEn transcripts were concentrated in the posterior mesencephalon and anterior metencephalon. In cultures of chick cranial neural crest cells (eight to nine somites; stage 9) ChickEn transcripts were localized in a subset (approx. 8\%) of cells examined after 2 days in culture.

A mouse monoclonal antibody, inv-4D9D4, made by Coleman and Kornberg recognizes the engrailedlike homeo domain of the engrailed and invected proteins (Martin-Blanco, Coleman, and Kornberg, personal communication). Patel, Coleman, Kornberg and Goodman (unpublished) have shown that this antibody binds to the hindbrain of 2-day-old chick embryos. We have confirmed these results and shown that this antibody binds to the same region of 4-day (stage 24) chick brains that in situ hybridization showed contained ChickEn transcripts. This antibody also recognizes a homeo domain-containing ChickEn peptide expressed as a beta-galactosidase fusion protein in Drosophila cell culture. We have not detected ChickEn protein in any tissue prior to eight to nine somites (stage 9). These results delineate the major expression pattern of the ChickEn gene during early (prior to stage 30) embryonic development in the chick.
Key words: ChickEn, neural crest, homeo box, RNA in situ, engrailed, chick development, brain

\section{INTRODUCTION}

The molecular mechanisms that underlie morphogenetic events are largely unknown. Recent advances in Drosophila developmental genetics have increased our understanding of the genetic control of pattern formation in the fruit fly. Many of the genes involved in Drosophila development contain a partially conserved internal region of $180 \mathrm{bp}$ called the homeo box (for review, see Gehring, 1987). Among the homeo box-containing genes, the engrailed and invected genes share distinctive homology both within and outside of the homeo box region (Poole et al., 1985; Coleman et al., 1987). Vertebrate engrailedlike genes have also been shown to share this extended homology (Darnell et al., 1986; Joyner and Martin, 1987).

The function of the Drosophila engrailed gene has been extensively studied (Garcia-Bellido et al., 1973; Lawrence and Morata, 1976; Kornberg, 1981a,b; Lawrence and Struhl, 1982; Lawrence and Johnston, 1984; Desplan et al., 1985; Karr et al., 1985; DiNardo et al., 1985; Ingham et al., 1985; Kuner et al., 1985; Weir and Kornberg, 1985; Weir and Lo, 1985; Kornberg et al.,1985; Poole et al., 1985; Macdonald and Struhl, 1986; Brower, 1986; Harding et al., 1986; Howard and Ingham, 1986). The engrailed gene belongs to the segmentation class of developmental genes that divide the Drosophila embryo into a repeating series of homologous segment primordia (Nusslein-Volhard and Wieschaus, 1980). The engrailed and invected genes are expressed

Received June 10, 1988; revised June 26, 1988; accepted June 30, 1988.

Address reprint requests to Kate F. Barald, Department of Anatomy and Cell Biology, University of Michigan, Ann Arbor, MI 48109. 
in the posterior compartment of each segment in the early fly embryo (Kornberg et al., 1985; DiNardo et al., 1985; Coleman et al., 1987). In engrailed mutants, posterior compartment development is defective in each segment (Kornberg, 1981). The engrailed and invected genes are later expressed in the Drosophila central nervous system (DiNardo et al., 1985; Ingham et al., 1985; Brower, 1986; Coleman et al., 1987).

Since the engrailed gene is important in Drosophila embryogenesis we sought to determine if an engrailedrelated gene might function similarly in chick development. Toward this end, a chicken gene that contains sequence homology to the engrailed-like homeo box and flanking conserved regions (ChickEn, Darnell et al., 1986) was cloned and partially sequenced.

To begin to define the possible function of the ChickEn gene we have analyzed its expression during early embryonic development (prior to stage 30). Our results show that while the ChickEn gene is expressed at low levels in many tissues, a higher level of expression is found in the central nervous system during the early stages of its development (stages 9-30). Using in situ hybridization we have further defined the major ChickEn gene expression pattern to a region restricted to the posterior mesencephalon and anterior metencephalon. Immunolocalization using an antibody that crossreacts with the ChickEn protein product shows similar patterns. In addition. in neural crest cell cultures made from early embryos (stage 9) preliminary results suggest that the ChickEn gene may be expressed in a subpopulation (approx. $8 \%$ ) of cranial neural crest cells, suggesting that expression of this gene might also be important in the development of neural crest derivatives in vivo.

\section{MATERIALS AND METHODS}

\section{Chickens}

Fertile White Leghorn chicken eggs were obtained from the Poultry Science Department of Michigan State University, East Lansing, or from the Petaluma Poultry Farm, Petaluma, CA. Eggs were maintained in a forcedraft incubator at $38-39^{\circ} \mathrm{C}$. Embryos were staged according to Hamburger and Hamilton (1951).

\section{Neural Crest Cell Cultures}

Cranial neural crest cultures from embryos (eight to nine somites; stage 9) were prepared on plastic coverslips as previously described (Barald, 1982, 1988).

\section{Northern Blot Hybridization}

For the majority of Northern blots discussed, chicks were dissected, and total RNA was extracted from tissue samples using LiCl (Auffray and Rougeon, 1980). Poly $(\mathrm{A})^{+}$RNA was isolated from total RNA using an

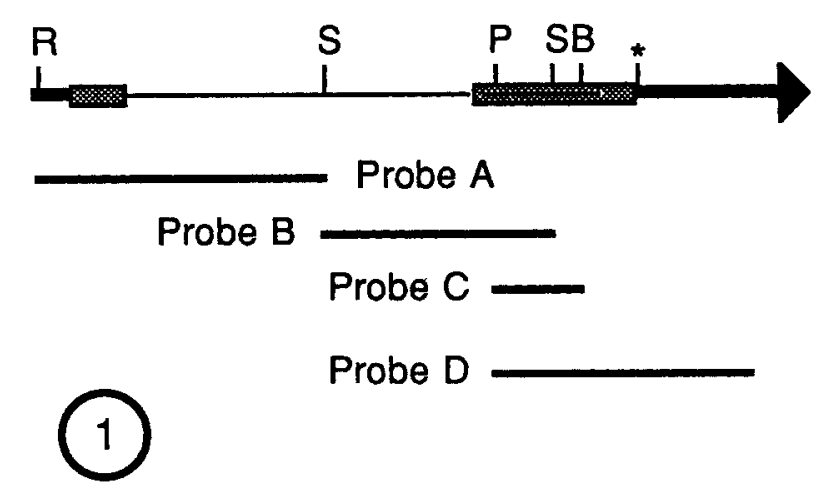

Fig. 1. Map of genomic clone region of the ChickEn gene used to generate probes for Northern blots and in situ hybridization. Restriction sites on map include EcoRI (R), SacI (S), PvuII (P), BglII (B). The asterisk indicates the termination of the open reading frame containing the homeo box. Unconserved sequence within exons is shown as a thick line, conserved sequence as a box, the homeo box as a line within a box, and intervening sequence as a thin line. Probes A (600 $\mathrm{bp})$, B (520 bp), and C (106 bp) were nick-translated probes generated from isolated EcoRI/SacI, SacI, and PvuII/BglII fragments of genomic DNA, respectively. Probe D (781 bp) was a riboprobe transcribed from the $\mathrm{T}_{3}$ promoter of Bluescript (Stratagene) and truncated at an internal Pvull site. All probes were used on Northern blots. Probe D was also used for in situ hybridization. Map is not to scale.

oligo-dT column (Pharmacia). Twelve micrograms of poly $(\mathrm{A})^{+}$RNA were loaded in a denaturing formaldehyde-agarose gel, fractionated by electrophoresis, and transferred to GeneScreen (NEN). RNA was bound to the membrane using ultraviolet (UV) irradiation (Church and Gilbert, 1984). Blots were prehybridized for $10 \mathrm{~min}$ and hybridized for $16 \mathrm{hr}$ at $65^{\circ} \mathrm{C}$ with $10^{7} \mathrm{cpm}$ per $\mathrm{ml}$ in $10 \mathrm{ml}$ of "moderate hybridization buffer" consisting of $1 \%$ bovine serum albumin (BSA), $0.2 \mathrm{M} \mathrm{NaPO}_{4}(\mathrm{pH}$ 7.2), $1.0 \mathrm{mM}$ EDTA, 7\% sodium dodecyl sulfate (SDS), and $35 \%$ formamide. ${ }^{32} \mathrm{P}$-labeled probes (probes A,B, and $\mathrm{C}$, Fig. 1) were made by nick translation from isolated fragments of genomic DNA. After hybridization and washing, the blot was exposed to Kodak X-Omat film at $-80^{\circ} \mathrm{C}$ with an intensifying screen. Size markers consisted of Hind III-digested lambda DNA end-labeled with ${ }^{32} \mathrm{P}$.

\section{In Situ Hybridization in Tissue Sections}

To remove RNase contamination, all glassware was baked for $4 \mathrm{hr}$ at $250^{\circ} \mathrm{C}$. All solutions were made in Diethyl Pyrocarbonate (DEPC)-treated water. Embryos were fixed with $4 \%$ paraformaldehyde in phosphate-buffered saline (PBS) with $\mathrm{MgCl}_{2}$ for 15 min on ice. Follow- 
ing fixation, 4-day old embryos were embedded in paraffin and sectioned at $8 \mu \mathrm{m}$. Sections were mounted on gelatin subbed slides and stored in a dessicated box until use. A 556-nucleotide antisense RNA probe (probe D, Fig. 1) was generated from a ChickEn genomic subclone in Bluescript (Stratagene) using the $T_{3}$ promoter. Immediately before hybridization slides were washed 2 $\times 10 \mathrm{~min}$ in xylene, $3 \times 10 \mathrm{~min}$ in $100 \%$ DEPC-EtOH, and allowed to air dry. Sections were incubated with probe $(400,000 \mathrm{cpm}$ per slide) overnight using the hybridization mixture (100 $\mu \mathrm{l}$ per slide) and conditions described by Jorgensen and Garber (1987).

For ${ }^{35} \mathrm{~S}$ autoradiography, slides were dipped in emulsion (Kodak NTB2) in the dark, and stored in a light-tight box with dessicant at $4^{\circ} \mathrm{C}$ for 11 to 28 days before developing. Tests of positive and negative chemography were routinely performed.

\section{In Situ Hybridization in Cultures of Cranial Neural Crest Cells}

Cells were fixed on plastic coverslips as above. To store neural crest cells before hybridization, fixative was removed and replaced with $0.3 \mathrm{M} \mathrm{NH}_{4} \mathrm{OAc}$. An equal volume of EtOH was added dropwise over a period of 10 min. This was removed, and the cells were stored in $100 \%$ DEPC-EtOH at $4^{\circ} \mathrm{C}$ overnight (Jorgensen and Garber, 1987). For hybridization, cells were allowed to air dry and were placed tissue side down on parafilm over $30 \mu \mathrm{l}$ of a mixture of probe $(120,000 \mathrm{cpm}$ per coverslip) and hybridization mix. Hybridization, washes, and autoradiography were as described above.

Cell aggregation in neural crest cultures made the counting of silver grains over some cells difficult. Only individual cells that could be completely visualized were counted among the labeled or unlabeled cells scored in each culture. The percentage of labeled cells observed therefore may not reflect a completely random sample.

\section{Immunolocalization in Drosophila Cell Culture}

The mouse monoclonal antibody inv-4D9D4 was provided by Coleman, Kornberg, and Goodman. This antibody was generated from a mouse immunized with the Drosophila invected protein (Coleman et al., 1987). The monoclonal antibody was found to crossreact with the Drosophila engrailed protein and recognizes an epitope within the homeo domain (Martin-Blanco, Coleman, and Kornberg, personal communication). The inv-4D9D4 antibody has been found to crossreact with proteins in a number of different species including chick (Patel, Coleman, Kornberg, and Goodman, unpublished).

To determine if the inv-4D9D4 antibody would recognize the ChickEn homeo domain, a fusion gene containing the engrailed-like conserved region was expressed and probed in Drosophila cell culture. The expression plasmid included the Drosophila heat-shock protein (hsp-70) promoter and first seven codons fused in frame to lacZ. A 900-bp ChickEn cDNA insert containing $800 \mathrm{bp} 5^{\prime}$ to the putative termination codon and including all known engrailed-like conserved regions was fused in frame to the $\mathrm{C}$ terminal end of lac $\mathrm{Z}$ and followed by the hsp-70 polyadenylation signal. The vector was a pUC13 derivative from which all lac $Z$ sequences had been removed. The beta-galactosidase expression plasmid, P-194.70ZT, was kindly provided by J. Lis. This control plasmid and the plasmid including the ChickEn sequences were transfected separately into Drosophila Schneider-2 cells (Dinocera and Dawid, 1983). After 24 $\mathrm{hr}$, the cells were washed, and after an additional $24 \mathrm{hr}$ the cells were resuspended in medium. Cells were allowed to settle onto glass cover-slips and heat shocked at $37^{\circ} \mathrm{C}$ for $30 \mathrm{~min}$ to ensure expression from the hsp- 70 promoter. Cells were returned to $25^{\circ} \mathrm{C}$ for $1.5 \mathrm{hr}$ to allow expression of the protein, then fixed with $3.7 \%$ formaldehyde in PBS for $15 \mathrm{~min}$. Following washing in PBS and permeabilization in PBS with $0.1 \%$ Triton X100 , cells were blocked with PBS containing $0.1 \%$ Triton $\mathrm{X}-100$ and $10 \%$ normal goat serum (PTN) for $1 \mathrm{hr}$. The primary antibodies were either a 1:1,000 dilution of rabbit anti-beta galactosidase (Cappel) in PTN or a $1: 1$ dilution of mouse monoclonal inv-4D9D4 in PTN. After $1 \mathrm{hr}$ the cells were washed for $1 \mathrm{hr}$ in PTN. The secondary antibody was either a 1:1,000 dilution of rhodaminelabeled goat anti-rabbit IgG (Cappel) or a 1:150 dilution of biotinylated horse anti-mouse IgG (Vector laboratories). After $1 \mathrm{hr}$, cells were washed, and inv-4D9D4treated cells were incubated with a 1:150 dilution of streptavadin-Texas Red (BRL) for $1 \mathrm{hr}$ and washed. Cells were stained with $1 \mu \mathrm{g} / \mathrm{ml}$ DAPI PBS for $5 \mathrm{~min}$, washed, mounted in Fluoromount G (Southern Biotechnologies), and visualized with fluorescence microscopy.

\section{Immunolocalization in Whole-Chick Embryos}

For whole-mount immunolocalization the following protocol was used (N. Patel, personal communication). Whole embryos were fixed for immunolocalization in the following solution: 0.1 M PIPES, $2 \mathrm{mM}$ EGTA, $1 \mathrm{mM}$ $\mathrm{Mg}_{2} \mathrm{SO}_{4}, 3.7 \%$ formaldehyde, $\mathrm{pH} 6.95$ for $1 \mathrm{hr}$, followed by $2 \times 10 \mathrm{~min}$ washes in PBS. Some embryos were incubated between washes for $5 \mathrm{~min}$ in PBS containing $3 \% \mathrm{H}_{2} \mathrm{O}_{2}$ to eliminate endogenous peroxidase activity. Embryos were then permeabilized by incubation in PBS containing $2 \mathrm{mg} / \mathrm{ml}$ BSA, $0.1 \%$ Triton X-100 (PBT) for $1 \mathrm{hr}$. All subsequent solutions used in antibody staining contained PBT. After permeabilization, whole embryos were washed twice with PBT and incubated in PBT with 5\% normal goat serum (PBT-NGS; Jackson Immuno Research Laboratory) for $30 \mathrm{~min}$. An equal volume of undiluted hybridoma supernatant containing 
the monoclonal antibody inv-4D9D4 was then added, and the mixture was incubated at $4^{\circ} \mathrm{C}$ overnight. Control embryos were incubated either without inv-4D9D4 or with an anti-rat monoclonal antibody [made to a preparation of rat synaptic extracellular matrix (Mizukami and Barald, unpublished)]. Following primary antibody incubation, embryos were washed twice with PBT followed by $3 \times 1 \mathrm{hr}$ in PBT to clear the primary. Incubation with PBT-NGS was repeated, and an equal volume of a 1:100 dilution of goat anti-mouse $\operatorname{IgG}$ directly conjugated to peroxidase (Jackson Immuno Research Laboratory) in PBT-NGS was added. Embryos were incubated for at least $5 \mathrm{hr}$ or up to overnight, followed by two washes in PBT and $3 \times 1 \mathrm{hr}$ in PBT. Embryos were then incubated in PBT with $3.3 \mathrm{mg} / \mathrm{ml}$ diaminobenzidine for $10 \mathrm{~min}$, after which $\mathrm{H}_{2} \mathrm{O}_{2}$ was added to a final concentration of $0.03 \%$. The reaction was allowed to continue and monitored using a microscope until complete.

\section{RESULTS}

\section{Northern Blot Hybridization}

Northern blots of poly(A) ${ }^{+}$or total RNA from tissues of early chick embryos were hybridized to probes derived from the genomic ChickEn clone (Figs. 1, 2). From embryonic day 4 (stage 24 ), three major bands migrating at approximately $2.2,3.5$, and $5.0 \mathrm{~kb}$ were detected. Hybridization signal was highest in poly $(\mathrm{A})^{+}$ RNA isolated from the head of day 4 (stage 24) embryos and brain of day 6 (stage 29-30) embryos (Fig. 2, lanes $1-3$ ) and was observed through day 18 (stage 44 , data not shown). The more prominent $2.2-$ and $3.5-\mathrm{kb}$ bands were detectable in total RNA from 2-day (stage 11-12) chick whole embryo (data not shown) and in poly(A) ${ }^{+}$ RNA from other embryonic tissues (day 4 body; day 6 body, viscera, flank, and neck). An example of this type of low-level hybridization is shown in Figure 2, lane 4. In some cases the $5.0-\mathrm{kb}$ band was also detected. All probes used to date contained some region of ChickEn sequence known to be conserved among the engrailedlike genes in flies and vertebrates (Joyner and Martin, 1987) (Frohman and Martin, personal communication).

Southern blot analysis of chick genomic DNA revealed strong hybridization to two bands, only one of which bears restriction fragment length similarity to the ChickEn clone (unpublished observation, Darnell and Ordahl). This second band may represent a ChickEnrelated gene. To determine if the bands detected in Figure 2 included transcripts from the ChickEn gene, cDNA clones were prepared from day 6 (stage 29-30) embryonic brain poly(A) ${ }^{+}$RNA. The nucleotide sequence of eight such cDNA clones is identical with the exonic regions of the ChickEn gene shown in Figure 1. No

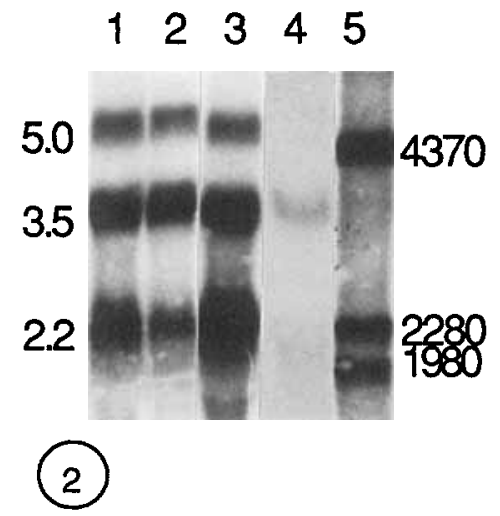

Fig. 2. Northern blots of chick poly(A) ${ }^{+}$RNA. Lane 1: Day 4 head, probe A (Fig. 1); lane 2: day 6 brain, probe A; lane 3: day 6 brain, probe B; lane 4: day 6 flank, probe C; lane 5: HindIII digested, end-labeled lambda DNA marker. Band intensities between lanes are not directly comparable because of RNA and probe concentration differences.

clones with divergent sequence have so far been identified. Thus, while we cannot rule out the possibility that we are examining expression of both engrailed-like genes, the cDNA data are consistent with expression of the ChickEn gene in early chick brain.

\section{In Situ Hybridization in Embryo Sections}

Because Northern blot hybridizations demonstrated transcript localization in brain, we used in situ hybridization to delineate the specific pattern of ChickEn gene expression in this region. Six sagittally sectioned embryos (day 4, stage 24; Fig. 3A-D shows two examples) were probed with ${ }^{35}$ S-labeled ChickEn antisense RNA (probe D, Fig. 1). Hybridization was observed in the posterior mesencephalon and anterior metencephalon (Fig. 3B). Less intense hybridization has been seen in the region of the developing eye (Fig. 3D), and possibly in the trigeminal nerve (not included in this section). We are presently seeking to define the exact nature of the hybridization seen outside the brain. No specific hybridization was seen when RNA probes made from random plasmid DNA (Riboprobe Gemini Positive Control Template, Promega Biotec) were used (six embryos) (see insert in Fig. 3).

\section{Monoclonal Antibody Staining}

Staining of the ChickEn gene product in Drosophila cell culture. Mouse monoclonal antibody inv-4D9D4 was made against the Drosophila invected gene by Coleman and Kornberg (unpublished). Monoclonal antibody inv4D9D4 has been shown to crossreact in the chick by Patel, Coleman, Kornberg, and Goodman (unpublished). 

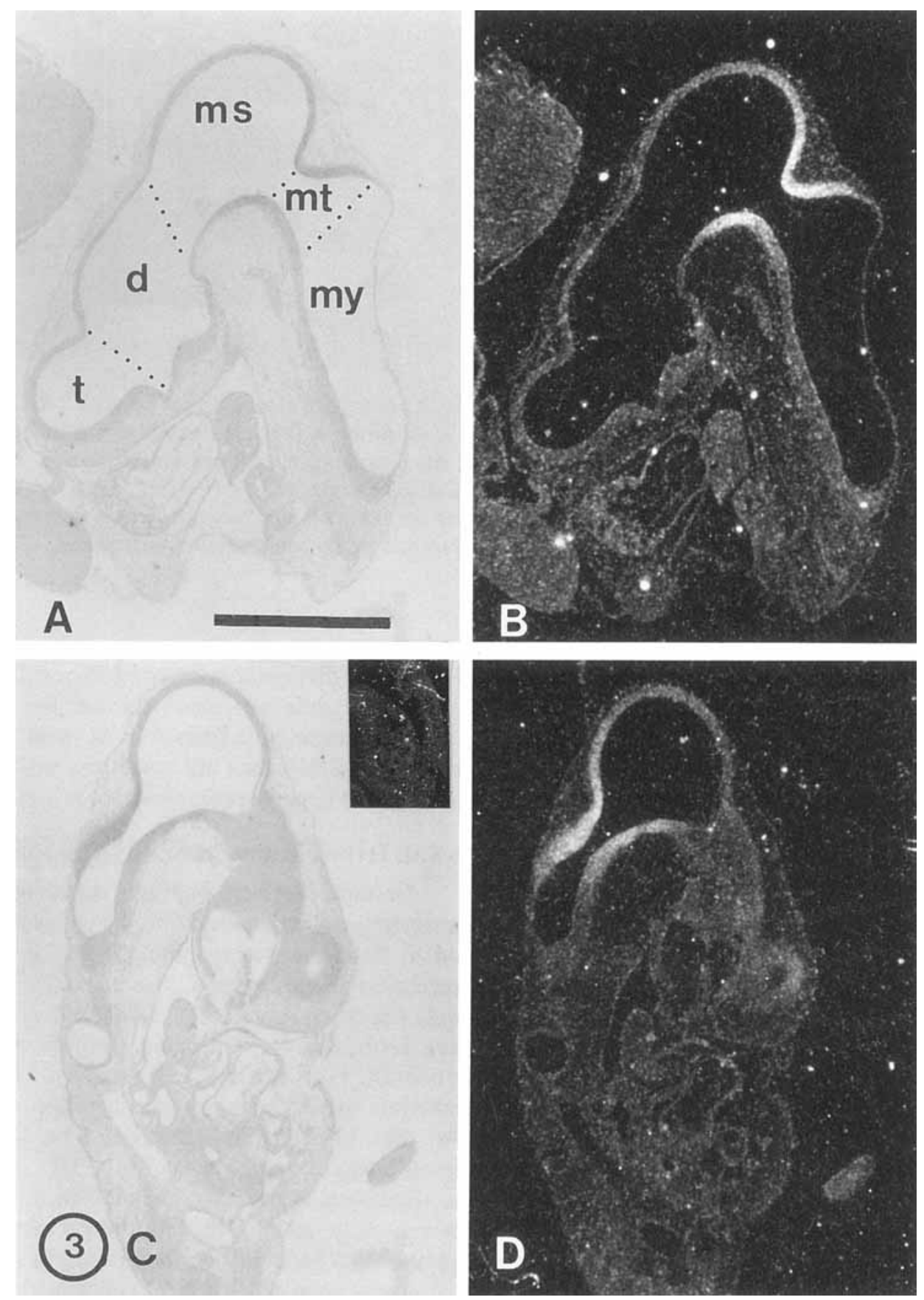

Fig. 3. Localization of ChickEn transcripts by in situ hybridization in midsagittal $(\mathbf{A}, \mathbf{B})$ and somewhat tangential $(\mathbf{C , D})$ sections of 4-day (stage 24 ) chick embryos; ${ }^{35}$ S-labeled probe D (see Fig. 1); 11 day exposure. Embryos were lightly stained with hematoxylin and eosin after hybridization and photographed with brightfield (left) and darkfield (right) illumina-

tion. $t$, telencephalon; $d$, diencephalon; ms, mesencephalon; mt, metencephalon; my, myelencephalon. Scale bar $=1 \mathrm{~mm}$. Insert represents the control, a stage- 24 embryo migsagittal section (1/5 scale). Probe used was an RNA copy of random plasmid DNA (Riboprobe Gemini Positive Control Template, Promega Biotec) (see "Materials and Methods"). 

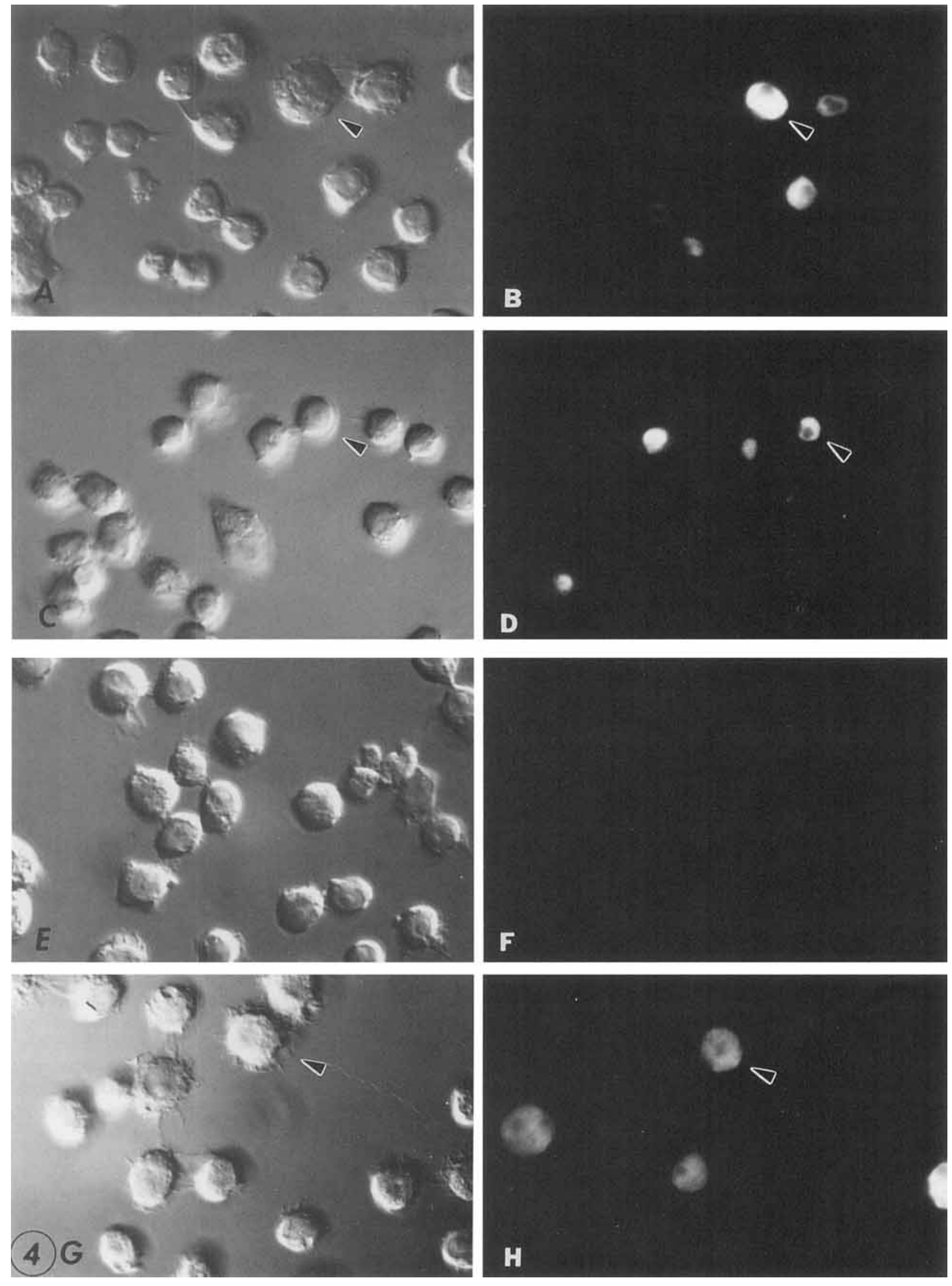

(Fig. 4 legend appears overleaf) 
To test whether this antibody could detect the engrailedlike ChickEn gene product, a fusion protein joining the approximately $270 \mathrm{C}$ terminal amino acids of the ChickEn protein to the $\mathrm{C}$ terminal end of beta-galactosidase was expressed in Drosophila cell culture. This fusion protein, which includes the ChickEn homeo domain and extended region of engrailed homology, is localized to the nuclei of cells and can be detected by immunofluorescence by both inv-4D9D4 and anti-beta-galactosidase antibodies (Fig. 4B,D). Beta-galactosidase alone (without the ChickEn sequences) is not detected by inv-4D9D4 (Fig. $4 F)$. Thus, this antibody does recognize the engrailedlike ChickEn protein. We have no information at this time about binding of inv-4D9D4 to the putative ChickEnrelated gene.

Monoclonal antibody staining in early chick embryos. Patel, Coleman, Kornberg, and Goodman (unpublished) have found that inv-4D9D4 stains specific regions of chick embryos as well as embryos of many other species. Since inv-4D9D4 recognizes the ChickEn protein we have sought to define the localization of ChickEn protein further using the inv-4D9D4 antibody on a wider range of chick embryonic stages. In this study, six embryos ranging from primitive streak to seven somites (stage 3-9) showed no localization of the monoclonal antibody. Eight embryos were examined ranging from eight to 21 somites (stage 9-13). Staining with inv-4D9D4 first appeared in eight to nine somite embryos in the dorsal neural tube (Fig. 5A). By 21 somites, staining intensity had increased and moved ventrally in the neural tube (Fig. 5C). Two 4-day-old (stage 24) embryos were examined (Fig. 6). In embryos older than eight to nine somites, staining was always seen in the posterior mesencephalon and anterior rhombencephalon (or meten-

Fig 4. Immunofluorescent detection of a beta-galactosidaseChickEn fusion protein in transfected cells. Drosophila Schneider-2 cells were transfected with an expression plasmid containing a lacZ-ChickEn in frame fusion gene or lacZ alone. After inducing expression of the proteins, cells were immunostained with either inv-4D9D4 or anti-beta-galactosidase antibodies. Cultures were transiently transfected so that only a subset of cells contained and expressed the plasmids. $\mathbf{A}$ and B: Cells transfected with the beta-galactosidase-ChickEn fusion plasmid and probed with inv-4D9D4; $C$ and $D$ : cells transfected with the beta-galactosidase-ChickEn fusion plasmid and probed with anti-beta-galactosidase. E and F: Cells transfected with the lac $Z$ control plasmid and probed with inv4D9D4. G and H: Cells transfected with the lacZ control plasmid and probed with anti-beta-galactosidase. A, C, E and $G$ are Nomarski DIC views, and $B, D, F$ and $H$ are immunofluorescent views of the same cells, respectively. Arrowheads identify identical cells in each treatment pair for orientation.
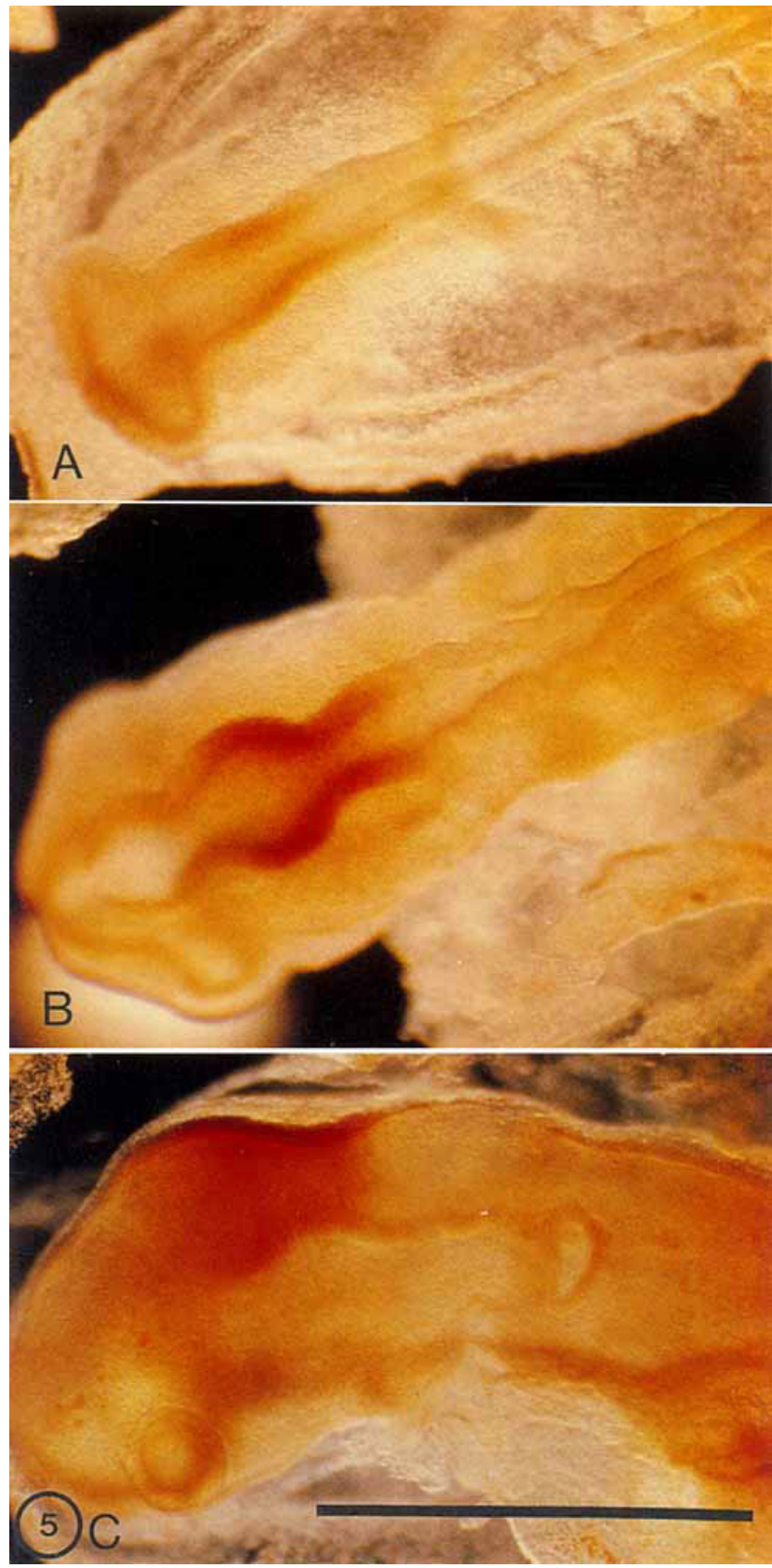

Fig. 5. Peroxidase-stained second-antibody localization of the monoclonal antibody inv-4D9D4, which has been shown (Fig. 4) to bind to the ChickEn protein product. Staining first appears in embryos with eight to nine somites (A: nine somites). Staining is more intense in $\mathbf{B}$ (16 somites) and is seen also at 21 somites, in $\mathbf{C}$. All embryos shown here were reacted together in the same dish. Scale bar $=1 \mathrm{~mm}$. 


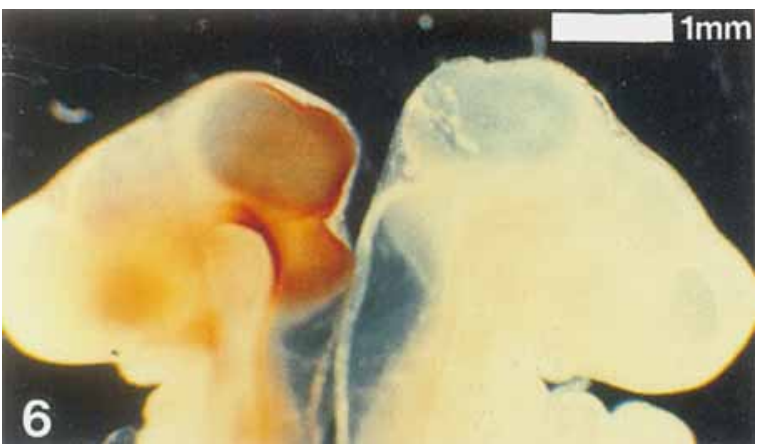

Fig. 6. Embryo stained with monoclonal antibody inv-4D9D4, as in Figure 5 to localize ChickEn protein. This embryo (4 days old; stage 24) was split in half. The left half was reacted with the monoclonal antibody and a secondary peroxidaseconjugated antibody; the right half of the embryo was reacted in secondary antibody without the primary antibody; both were treated with $\mathrm{H}_{2} \mathrm{O}_{2}$ to eliminate staining from endogenous peroxidases. Similar results to those shown for the control were also obtained using another monoclonal antibody to rat extracellular matrix (see "Materials and Methods").

cephalon: the name of the labeled region changes with the division of rhombencephalon into metencephalon and myelencephalon between ten and 14 somites, stages 10 and 11). Examination of staining in 4-day-old embryos suggests that there may be less intense antibody localization elsewhere, for example in the region of the developing eye, trigeminal nerve, and in an as yet undefined set of cells near the ventral midline. At high magnification, staining was seen to be localized in cell nuclei.

When embryos were incubated without inv-4D9D4, or with an anti-rat synaptic extracellular matrix monoclonal antibody (Mizukami and Barald, unpublished), specific staining in the neural tube, brain, or elsewhere was not seen. Three percent $\mathrm{H}_{2} \mathrm{O}_{2}$ in PBS for $5 \mathrm{~min}$ following fixation eliminated most endogenous peroxidase activity (for example, in blood cells) but did not eliminate the specific nervous system-associated staining (Fig. 6).

This pattern of antibody localization is consistent with the transcript localization seen using ChickEn antisense RNA probes for in situ hybridization in day 4 (stage 24) embryo sections (compare Figs. 3b and 6). In preliminary experiments, antibody staining in sections adjacent to those used for in situ hybridization further supports this conclusion (data not shown).

\section{In Situ Hybridization in Cultured Cranial Neural Crest Cells}

Because the ChickEn gene is expressed in the mesencephalon and metencephalon, and because a small number of unidentifiable cells that are possibly neural crest cells have been seen by in situ hybridization with autoradiographic grains, we examined cultures of the neural crest cells that emigrate from this region in order to determine whether they too expressed the gene. Cells were cultured in order to isolate a large number and a relatively pure population of cells, apart from the neural tube.

Autoradiographic labeling of cranial neural crest cell cultures from three different neural tube preparations was independently counted by two observers (total number of cells counted $=2,027$ ). The percentage of cells containing a substantially higher number of silver grains over the cell body compared to background/"unlabeled" cells was determined, and the means from the two observations of each set of cultures were then averaged: 8.3 $\pm 2.7 \%$ (S.E.M.) labeled cells per culture were found (Fig. 7).

Grain counts from 700 cells showed that cells counted as "unlabeled" ranged from zero to nine silver grains directly over each cell. The average background/ unit area of the emulsion (not over cells) that corresponded to an average cell unit area was nine grains. Background level grains were always subtracted from the cell grain counts. A lightly labeled group of cells (44 cells) had five grains/cell over background. Labeled cells ranged from 45 to 145 silver grains directly over each cell (at least four times background) (Fig. 7A-F and histogram, Fig. 8). No specific hybridization to any cells in the culture was seen when RNA probes made from random plasmid DNA (Riboprobe Gemini Positive Control Template, Promega Biotec) were used to label sister cultures (not shown).

\section{DISCUSSION}

\section{Localization of the ChickEn Gene in the Developing Nervous System; Comparisons With engrailed Genes of Other Species}

We have sought to localize the expression of the ChickEn gene during early stages of chick development using Northern blot hybridization, in situ hybridization, and immunolocalization. Results from these experiments demonstrate localized expression of the ChickEn gene in defined regions of the mesencephalon and rhombencephalon as early as eight to nine somites (stage 9) and in the derivatives of these regions at subsequent stages. The engrailed and ChickEn genes share extensive sequence homology. The engrailed gene plays a significant role in pattern formation in the early Drosophila embryo and is also expressed in the embryonic nervous system.

Northern blot hybridization data show that at day 4 (stage 24) ChickEn gene expression is localized in the head, and that the ChickEn gene may continue to be expressed in the brain at least up to day 18 (stage 44) of 

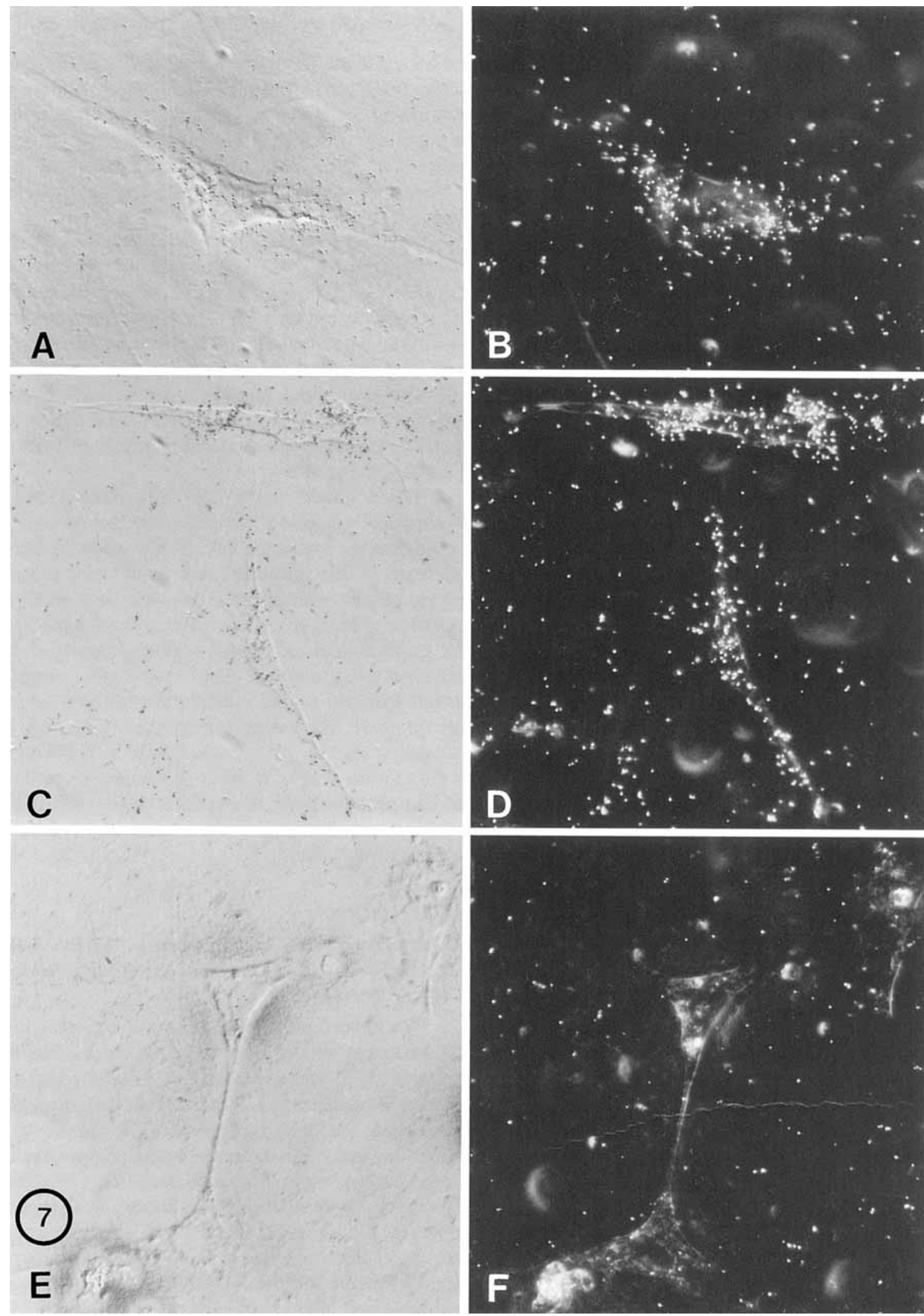

Fig 7. Examples of labeled (A-D) vs. unlabeled (E,F) cells in cultures of cranial neural crest hybridized with ${ }^{35}$ S-labeled cells in such cultures were labeled. Cells were photographed with brightfield (left) and darkfield (right) illumination. Original magnification $\times 600$. 


\section{In Situ Hybridization to Cultured Neural Crest Cells}

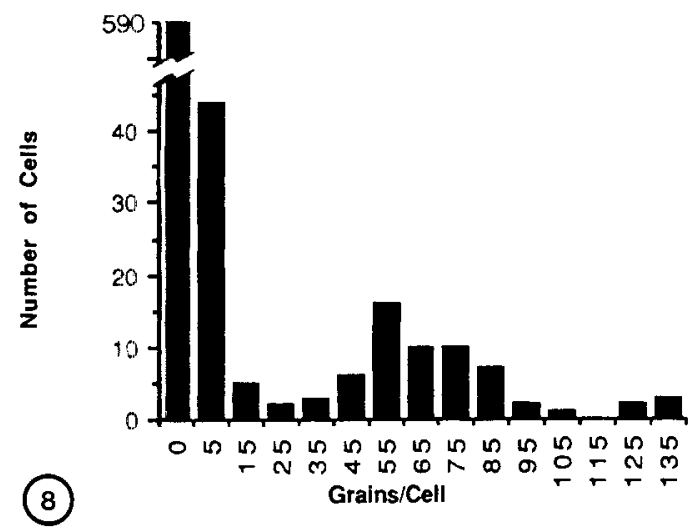

Fig. 8. Histogram of grain counts over cells in cultures of cranial neural crest cells processed for in situ hybridization after 2 days in culture. Seven hundred cells were counted. Unlabeled cells were those with nine grains or fewer over their cell bodies (the same level of grains found over cell-free regions of the culture). Such unlabeled cells are depicted in the "O" column of the graph (589/700 cells). Labeled cells (those with greater than $\mathbf{4 5}$ grains/cell) are seen in this bimodal distribution. The upper number of grains is indicated under each bar; i.e. " 5 " means $0-5$ grains/cell; " 15 " means 5-15 grains/cell, etc.

embryonic development. We have observed three major bands of hybridization $(2.2,3.5$, and $5.0 \mathrm{~kb})$. In the mouse, two engrailed related genes have been identified, called En-1 and En-2 (Joyner et al., 1985; Joyner and Martin, 1987). Davis et al. (1988) found that what initially appeared to be three transcripts of the mouse engrailed-like gene, En-2, turned out to include two highly abundant but unrelated transcripts with weak homology to an $E n-2$ upstream region. We find hybridization to the $2.2,3.5$, and $5.0 \mathrm{~kb}$ bands for all probes used to date, including a probe restricted to the homeo box region (probe C, Fig. 1). Therefore, we believe that the three major bands seen on our blots are not due to nonspecific hybridization, but to hybridization with ChickEn transcripts and possibly the putative ChickEn-related gene transcripts. Eight clones isolated from a day 6 (stage 2930) chick brain cDNA library have been sequenced to date. All share complete nucleotide sequence identity with exonic regions of the ChickEn gene. No cDNA attributable to the putative ChickEn-related gene has yet been identified from this library. Therefore, at least some of the transcripts detected on Northern blots must arise from the ChickEn gene. However, since no probe has yet been shown by Southern blot hybridization to be specific to the ChickEn gene, further work is necessary to establish whether each of the RNA bands shown in Figure 2 represents a transcript of the ChickEn gene or whether some may be encoded by the putative ChickEn-related gene.
Labeled cells in 4-day (stage 24) chick embryo sections that were hybridized to ChickEn antisense RNA probes revealed specific expression of the ChickEn gene in a discrete region of the early developing nervous system (Fig. 3). Cells in this region (mes-metencephalon) appear otherwise morphologically indistinguishable from more rostral or caudal cells of the developing brain at this stage. This labeling is seen in the same region in which staining of the monoclonal antibody inv-4D9D4 is also seen (Fig. 6). We have confirmed that inv-4D9D4 recognizes the ChickEn gene product (Fig. 4). We therefore believe that the antibody staining pattern seen in early chick embryos represents, at least in part, localization of the ChickEn gene product.

In situ hybridization and immunolocalization both suggest expression of the ChickEn gene elsewhere, for example in the region of the eye (Figs. 3, 6) and of the trigeminal nerve. These observations need further investigation.

It is interesting to note that the spatial pattern of engrailed-like gene expression has been conserved in at least two vertebrate classes. The pattern of ChickEn gene expression described here resembles the expression patterns described by Davis et al. (1988) for En-2 in situ hybridization in the mouse. Cells of the mouse hindbrain and many of their descendants continue to express $E n-2$ strongly throughout development (Davis et al., 1988). Our Northern analyses suggests that this may also be true of the ChickEn gene.

\section{Expression of ChickEn in Cultures of Cranial Neural Crest Cells}

We have also found that the ChickEn gene is expressed in a subset of cultured presumptive cranial neural crest cells. These cells normally migrate in vivo from the mesencephalon and/or metencephalon. This is the first report of possible homeo box-containing gene expression in what may be neural crest cells prior to their subsequent differentiation into other cell types. A small subpopulation of cells in what may be premigratory cranial crest in the mes-metencephalic region has been seen in our preliminary in situ hybridization studies of stage 8-9 embryos.

Neural crest cells contribute to the development of cranial, sensory, and sympathetic ganglia, which are arranged in segmental patterns along the length of the embryo (LeDouarin, 1983; 1986). The expression of the ChickEn gene in a subset of these cells is consistent with the possible role for vertebrate homeo box-containing genes in the differentiation of this migratory cell population. Toth et al. (1987) have demonstrated expression of a homeo box-containing gene, Hox 1.4 , in the crestderived cervical sensory ganglia of the mouse at embryonic day 11.5; no earlier stages have been examined. 
The mesencephalic-metencephalic region in which ChickEn gene expression is observed is the same region from which a subpopulation of neural crest cells destined to contribute to the formation of the ciliary and trigeminal ganglia emigrate (Noden, 1978; LeDouarin et al., 1978; Narayanan and Narayanan, 1978; D'Amico-Martel and Noden, 1983). Barald $(1982,1988)$ has used monoclonal antibodies to identify a neural crest subpopulation (about $5 \%$ of cells) from this region, which may contribute to the formation of the ciliary ganglion (Barald, 1982, 1988). We are attempting to identify the cells with a high density of autoradiographic grains that appear in presumptive premigratory neural crest cells, which we have seen in sectioned embryos. Experiments in progress include in situ hybridization to sections of embryos fixed during times of cranial and trunk crest emigration (eight to 30 somites, stages 9-17) to localize cells outside the neural tube that may express the ChickEn gene and to determine whether ChickEn gene expression in these cells is seen only in culture. It is possible that the lack of identifiable staining in the neural crest in whole embryos with the monoclonal antibody inv-4D9D4 (Fig. 5) reflects the small percentage $(8 \%)$ of cells in culture that express the ChickEn gene or possibly a low level of the protein in these cells. We have also not ruled out the possibility that the cells that express the ChickEn gene in neural crest cultures might be mesodermally derived head mesenchyme cells that could possibly contaminate this population. Experiments are presently underway with neural crest-specific monoclonal antibodies that identify all or subpopulations of crest cells to define the population further.

\section{A Role for ChickEn in Development?}

We have established that the ChickEn gene is expressed in a discrete region of the developing chick brain. This is consistent with a possible role for the ChickEn gene in neural development. The ChickEn gene expression pattern does not resemble that found for the engrailed gene in Drosophila, except in that the engrailed gene is expressed in Drosophila neural tissue (DiNardo et al., 1985; Ingham et al., 1985; Brower, 1986; Coleman et al., 1987). It cannot be ruled out however, that the ChickEn gene may be expressed transiently during development, or at such low levels in other tissues that it has not yet been detected by in situ hybridization or immunolocalization in a pattern related to the segmentation of the early chick embryo.

It is not yet known if homeo box-containing genes like the ChickEn gene are involved in morphogenetic processes in vertebrates similar to those in flies. Since homeo box-containing proteins including the ChickEn gene product localize to nuclei (e.g., White and Wilcox, 1984; Beachy et al., 1985; Carroll and Scott, 1985;
DiNardo et al., 1985; Carroll et al., 1986; Wirz et al., 1986; Macdonald and Struhl, 1986; Frasch et al., 1987) (inv-4D9D4, Patel, Coleman, Kornberg, and Goodman unpublished; this paper); it is possible that these genes play similar roles at the cellular level without necessarily playing identical morphogenetic roles in development. We believe that further investigation of ChickEn gene expression in the chick central nervous system and in the neural crest during development will allow us to examine important questions of cell lineage and neuronal maturation.

\section{ACKNOWLEDGMENTS}

We would like to thank Kevin Coleman, Thomas Kornberg, Nipam Patel, and Corey Goodman for providing the inv-4D9D4 antibody; Nipam Patel and Corey Goodman for protocols and many helpful discussions; J. Lis for providing P-194.70ZT; and Lynn Acosta, Janet Braisted, Mark Laus, Jae Lee, and Parker Antin for providing excellent technical assistance. We would also like to thank Margaret Lomax for advice and many valuable discussions. This work was supported by grants from the NSF (PCM 17271), the NIH, and the Dysautonomia Foundation to K.F.B., by a University of Michigan Research Partnership Grant to C.A.G. and K.F.B., and by Developmental Biology Training Grant support to C.A.G. D.K.D. and C.P.O. were supported by grants from NIH.

\section{REFERENCES}

Auffray C, Rougeon F (1980): Purification of mouse immunoglobulin heavy chain messenger RNAs from total myeloma tumor RNA. Eur J Biochem 107:303-314.

Barald KF (1982): Monoclonal antibodies to embryonic neurons: Cell-specific markers for chick ciliary ganglion. In Spitzer NC (ed): "Neuronal Development." New York: Plenum. pp 101119.

Barald KF (1988): Monoclonal antibodies made to chick mesencephalic neural crest cells and to ciliary ganglion neurons identify a common antigen on the neurons and a neural crest subpopulation. J Neurosci Res 21:107-118.

Beachy PA, Helfand SL, Hogness DS (1985): Segmental distribution of bithorax complex proteins during Drosophila development. Nature 313:545-551

Brower DL (1986): engrailed gene expression in Drosophila imaginal discs. EMBO J 5(10):2649-2656.

Carroll SB, MP Scott (1985): Localization of the fushi tarazu protein during Drosophila embryogenesis. Cell 43:47-57.

Carroll SB, Laymon RA, McCutcheon MA, Riley PD, Scott MP (1986): The localization and regulation of Antennapedia protein expression in Drosophila embryos. Cell 47:113-122.

Church GM, Gilbert W (1984): Genomic sequencing. Proc Natl Acad Sci USA 81:1991-1995.

Coleman KG, Poole SJ, Weir MP, Soeller WC, Kornberg T (1987): The invected gene of Drosophila: Sequence analysis and expression studies reveal a close kinship to the engrailed gene. Genes Dev 1: 19-28. 
D'Amico-Martel A, Noden DM (1983): Contributions of placodal and neural crest cells to avian cranial peripheral ganglia. Am J Anat 166:445-468.

Darnell DK, Kornberg T, Ordahl CP (1986): ChickEn: A chick genomic clone with homology to the Drosophila engrailed homeo box. J Cell Biol 103(5):311a.

Davis CA, Noble-Topham SE, Rossant J, Joyner AL (1988): Expression of the homeo box-containing gene $E n-2$ deliniates a specific region of the developing mouse brain. Genes Dev 2:361371

Desplan C. Theis J, O'Farrell PH (1985): The Drosophila developmental gene, engrailed, encodes a sequence-specific DNA binding activity. Nature 318:630-635.

DiNardo S. Kuner JM, Theis J, O'Farrell PH (1985): Development of embryonic pattern in Drosophila melanogaster as revealed by accumulation of the nuclear engrailed protein. Cell 43:5969

Dinocera P. Dawid I (1983): Transient expression of genes introduced in cultured cells of Drosophila. Proc Natl Acad Sci USA 80: $7095-7098$.

Frasch M. Hoev T, Rushlow C, Doyle H, Levine M (1987): Characterization and localization of the even-skipped protein of Drosophila. EMBO J 6:749-759.

Garcia-Bellido A, Ripoll P, Morata G (1973): Developmental compartmentalization of the wing disk of Drosophila. Nature New Biol 245:251-253.

Gehring WJ (1987): Homeo boxes in the study of development. Science 236(4806): 1245-1252.

Hamburger V, Hamilton HL (1951): A series of normal stages in the development of the chick embryo. J Morphol 88:49-92.

Harding K. Rushlow C, Doyle HJ, Hoey T, Levine M (1986): Crossregulatory interactions among pair-rule genes in Drosophila. Science 233:953-959.

Howard K. Ingham P (1986): Regulatory interactions between the segmentation genes fushi tarazu, hairy, and engrailed in the Drosophila blastoderm. Cell 44:949-957.

Ingham PA, Martinez-Arias A, Lawrence P, Howard K (1985): Expression of engrailed in the parasegments of Drosophila. Nature 317:634-636.

Jorgensen EM. Garber RL (1987): Function and misfunction of the two promoters of the Drosophila Antennapedia gene. Genes Dev 1:544-555.

Joyner AL. Kornberg T, Coleman KG, Cox DR, Martin GR (1985): Expression during embryogenesis of a mouse gene with sequence homology to the Drosophila engrailed gene. Cell 43:29-37.

Joyner A, Martin G (1987): En-1 and En-2, two mouse genes with sequence homology to the Drosophila engrailed gene: Expression during embryogenesis. Genes Dev 1:29-38.

Karr TL, Ali Z, Drees B, Kornberg T (1985): The engrailed locus of $D$. melanogaster provides an essential zygotic function in precellular embryos. Cell 43:591-601.

Kornberg T (1981a): engrailed: A gene controlling compartment and segment formation in Drosophila. Proc Natl Acad Sci USA 78:1095-1099.
Kornberg T (1981b): Compartments in the abdomen of Drosophila and the role of the engrailed locus. Dev Biol 86:363-372.

Kornberg T, Siden I, O'Farrell P, Simon M (1985): The engrailed locus of Drosophila: In situ localization of transcripts reveals compartment-specific expression. Cell 40:45-53.

Kuner JM, Nakanishi M, Ali Z, Drees B, Gustavson E, Theis J, Kauvar L, Kornberg T, O'Farrell PH (1985): Molecular cloning of engrailed: A gene involved in the development of pattern in Drosophila melanogaster. Cell 42:309-316.

Lawrence PA, Morata G (1976): Compartments in the wing of Drosophila, a study of the engrailed gene. Dev Biol 50:321-337.

Lawrence PA, Struhl G (1982): Further studies of the engrailed phenotype in Drosophila. EMBO J 1:827-833.

Lawrence PA, Johnston P (1984): On the role of the engrailed $^{+}$gene in the internal organs of Drosophila. EMBO J 3(12):28392844.

LeDouarin NM, Teillet MA, Ziller C, Smith J (1978): Adrenergic differentiation of cells of the cholinergic ciliary and Remak ganglia in avian embryo after in vivo transplantation. Proc Natl Acad Sci (USA) 75:2030-2034.

LeDouarin NM (1983): "The Neural Crest." London: Cambridge University Press.

LeDouarin NM (1986): Cell line segregation during peripheral nervous system ontogeny. Science $231: 1515-1522$

Macdonald PM, Struhl G (1986): A molecular gradient in early Drosophila embryos and its role in specifying the body pattern. Nature 324:537-545.

Narayanan CH, Narayanan Y (1978): On the origin of the ciliary ganglion in birds studied by the method of interspecific transplantation of embryonic brain regions between quail and chick. J Embryol Exp Morphol 47:137-148.

Noden DM (1978): The control of avian cephalic neural crest cytodifferentiation II neural tissues. Dev Biol 67:313-329.

Nusslein-Volhard C, Wieschaus E (1980): Mutations affecting segment number and polarity in Drosophila. Nature 287:795-801.

Poole SJ, Kauvar LM, Drees B, Kornberg T (1985): The engrailed locus of Drosophila: Structural analysis of an embryonic transcript. Cell 40:37-43.

Toth LE, Slawin KL, Pintar JE, Nguyen-Huu CM (1987): Regionspecific expression of mouse homeo box genes in the embryonic mesoderm and central nervous system. Proc Natl Acad Sci USA 84:6790-6794.

Weir MP, Kornberg T (1985): Patterns of engrailed and fushi tarazu transcripts reveal novel intermediate stages in Drosophila segmentation. Nature 318:433-439.

Weir MP, Lo CW (1985): An anterior/posterior communication compartment border in engrailed wing discs: Possible implications for Drosophila pattern formation. Dev Biol 110:84-90.

White RAH, Wilcox M (1984): Protein products of the bithorax complex in Drosophila. Cell 39:163-171.

Wirz J, Fessler LI, Gehring WJ (1986): Localization of the Antennapedia protein in Drosophila embryos and imaginal discs. EMBO J 5:3327-3334. 